\title{
Smiling factory: Early rehabilitation of two young children with ectodermal dysplasia - Case reports
}

\author{
Perry JE ${ }^{1}$, Perry $\mathrm{S}^{1}$, Soto $\mathrm{DM}^{1}$, Cline $\mathrm{JA}^{2}$ and Mugayar $\mathrm{LR}^{2 *}$ \\ ${ }^{1}$ Department of Prosthodontics, University of Florida College of Dentistry, USA \\ ${ }^{2}$ Department of Pediatrics, University of Florida College of Dentistry, USA
}

\begin{abstract}
Ectodermal dysplasia (ED) is an inherited disorder characterized by the abnormal development of ectodermally derived anatomic structures, with features such as onchodysplasia, trichodysplasia, dyshidrosis, and oligodontia. Hypoplasia of the alveolar ridges is also associated and removable prosthodontics is the most common treatment modality for dental management. Oral rehabilitation is recommended for the positive development of self-esteem as well as for improved speech, masticatory function and facial esthetics. The purpose of this article is to present early prosthetic rehabilitation of two toddlers or very young patients with ED, aiming to contribute to enhance the current literature, considering that it does not provide much information on this topic.
\end{abstract}

\section{Background}

Ectodermal dysplasia (ED) is an inherited disorder characterized by the abnormal development of ectodermally derived anatomic structures [1] and was defined by Freire-Maia [2,3] as any syndrome with at least two of the following features: onchodysplasia, trichodysplasia, dyshidrosis, anodontia or oligodontia. Midface hypoplasia is frequently observed along with other orofacial characteristics including hypoplastic conical teeth, underdevelopment of the alveolus, a pronounced supraorbital ridge and frontal bossing, depressed nasal bridge, and protuberant everted lips due to a decreased facial vertical dimension [4-7]. Patients with ED have also demonstrated hypoplasia and aplasia of major salivary glands therefore may exhibit varying degrees of xerostomia $[8,9]$.

With over 190 different types of ED syndromes reported [10], clinical presentation depends on the specific type afflicting the patient. The two major types are hypohidrotic, where the sweat glands are absent or significantly decreased, and hidrotic, in which the sweat glands are normal. The most frequently reported ED syndrome is the X-linked hypohidrotic ED [11], also known as Christ-SiemensTouraine syndrome [12] or Clouston [13], with a reported incidence of 1/10,000 births [14]. Hypohidrotic ED can also be associated with sensitivity to heat, frequent high fevers, and is associated with more dental defects [15].

Hypodontia of the primary and permanent dentition and associated hypoplasia of the alveolar bone with poorly formed alveolar ridges are both commonly occurring $[4,16]$. Removable prosthodontics is the most common treatment modality for the dental management of ED [17] often providing an acceptable esthetic and functional result; however, hypoplasia of the edentulous alveolar ridges can significantly compromise retention and stability of a removable prosthesis. When teeth are present, they are often conical in shape, making them less than ideal as removable partial denture abutments. These teeth can however be used as an option for abutments with conventional complete overdentures [18-20], whose advantage of preserving bone makes it the desired treatment for the young ED patient [17,21-28].
Several studies have reported the successful use of endosteal implants for the treatment of ED [29-33]. Implants could preserve alveolar bone and improve the psychological well-being of the patient [34,35], however caution should be used in placing implants in children since they could become malpositioned or displaced if placed during active growth $[32,36]$. Several clinical reports have demonstrated the use of dental implants to rehabilitated patients with ED [37-39], however few prospective clinical trials of implants placed in the young ED patient have been published [15].

The appearance of patients with ED can affect their social and psychological development [40], therefore oral rehabilitation is recommended for the positive self-esteem development. Additionally, improved speech, masticatory function and facial esthetics contribute to normal dietary habits and social development [41,42]. While individuals with ED report more issues with chewing, swallowing, dry mouth and speech, orofacial function has not been studied systematically [43]. Oral-motor exercises (OME) can be incorporated for patients who have feeding and swallowing problems [44] with the goal of aiding in adjusting to prostheses. OMEs include stretching, massage, vibration, and passive range of motion exercises with the assistance of a caregiver. These procedures are applied to provide sensory input and it has been theorized these techniques normalize feeding patterns by reducing abnormal oral reflexes, facilitating normal muscle tone, or desensitizing the oral region [45]. Although clinical evidence is not yet available for these principles, reasonable rationale for their use has been provided [45]. The addendum at the end of the article provides desensitization instructions and steps to follow regarding OMEs (Tables 1 and 2).

Correspondence to: Mugayar LR, Department of Pediatrics, University of Florida College of Dentistry, USA, E-mail: LMugayar@dental.ufl.edu

Received: September 13, 2016; Accepted: October 26, 2016; Published: October 31, 2016 
Table 1. Instructions for Desensitization.

Always use a gentle but firm stroking movement.

Discontinue use with any aversive response to stimuli and regress to previous step.

Talk about what you are doing in calm manner and give praise for tolerating a step.

Do not rush through steps; desensitization can take time, varying individually.

Always start with step 1 at each session, even if early steps are well tolerated.

Exercises should be done 2-3 times every day.

Table 2. Instructions for Desensitization.

Using both hands, start in the middle of the

forehead and stroke out to the top of the ear.

Starting at the cheekbone, stroke firmly

down to the center of the chin.

\section{용

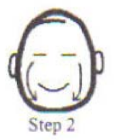

Stroke from one side of the lower lips to the

other. Repeat on the upper lip, starting from the

center to corners of the mouth, repeat 4-5 times

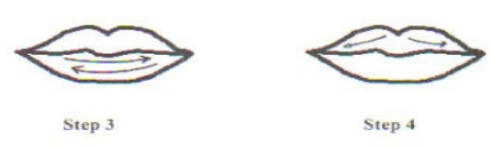

Divide inside of the mouth into 4 parts.

Place index finger on the gingiva and work from

front to back one way, not rubbing continuously

back and forth, be careful not to touch frenum.

Repeat 10 times one way, then continue onto the

other areas of the mouth in the same way.

\section{Aim}

The purpose of this article is to present early prosthetic rehabilitation of two young patients with ED. Informed consent was obtained from the parents of the participating subjects.

\section{Case report}

\section{Patient 1}

A 3-year, 8 month old female (Caucasian Caucasian was referred to the Department of Pediatric Dentistry, University of Florida in Gainesville, FL for evaluation and treatment. She presented with classical features of hypohidrotic ED including diffusely sparse hair, hypohidrosis, onchodysplasia, oligodontia, and impaired hearing. The facial profile showed a depressed nasal bridge, prominent forehead, and the lower third of the face was deficient, consistent with decreased vertical dimension of occlusion (Figures $1 \mathrm{a}$ and $1 \mathrm{~b}$ ). Intraoral examination revealed macroglossia, minimal keratinized tissue, adequate salivary flow, oligodontia, underdeveloped alveolar ridge, shallow vestibular space and flat palatal vault (Figure 2). Radiographic examination confirmed clinical findings and revealed only primary mandibular second molars with conical contours and permanent mandibular first molars were present bilaterally. Severe hypotonicity of the peri-oral and masticatory muscles was apparent with reported difficulty in speech and mastication. The mother also presented with similar oligodontia, reporting she only had her mandibular first molars present and had been wearing a complete maxillary denture and mandibular removable partial denture since the age of eight .

In view of the patient's age, good behavior, and with the mother's understanding of the syndrome, a maxillary complete denture and a mandibular complete overdenture were determined to be the treatment of choice. Preliminary impressions were made with modeling plastic impression compound (Red Cake, Kerr Corporation; Orange, CA). Custom trays were fabricated with light-polymerized acrylic resin (Triad TruTray, Dentsply; York, PA) and definitive border molding and
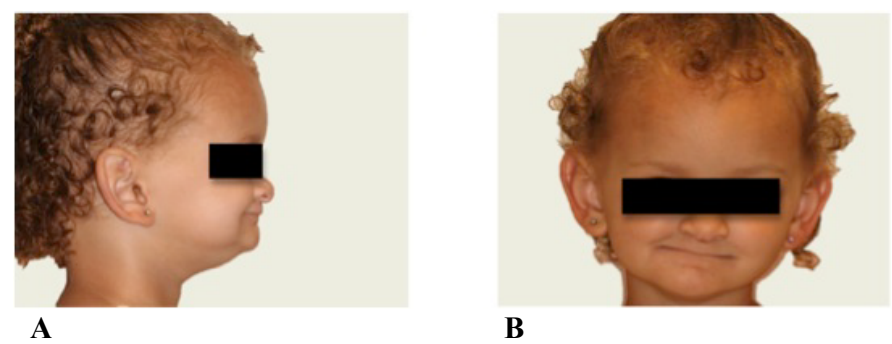

Figure 1. A, B. Full facial and profile views of the patient, illustrating the deficient proportion of the lower third of the face.

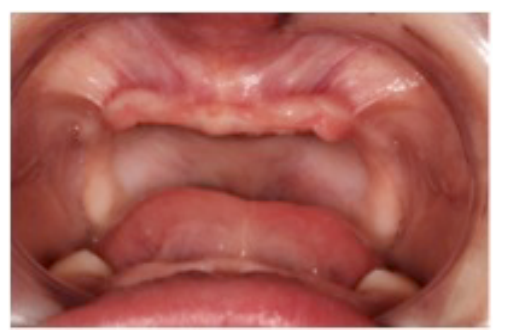

Figure 2. Intraoral examination revealed severe hypodontia with only the primary mandibular second molars present.

impressions were made using polyvinylsiloxane impression material (Aquasil, Dentsply Caulk; Milford, DE). Maxillomandibular relation records were made using wax occlusion rims and the casts mounted on a semi-adjustable articulator. Prosthetic deciduous denture teeth (Bambino, Pearson Lab; Sylmar, CA) were adjusted and arranged for an age appropriate appearance. The vertical dimension of occlusion, lingualized-balanced occlusal wax trial denture and the positions of the prosthetic teeth were evaluated intraorally, and adjustments were made at this time (Figures 3 and 4). The dentures were then processed with heat-activated acrylic resin (Lucitone 199 Original, Dentsply; York, PA).

Upon insertion of the dentures, the vertical dimension of occlusion 


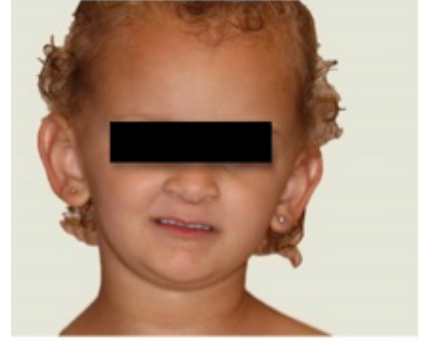

A

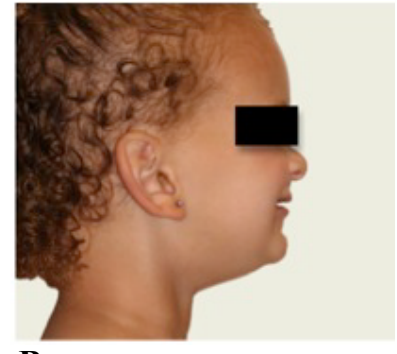

B
Figure 3. A, B. Wax trial denture with verified tooth position and corrected vertical dimension of occlusion.

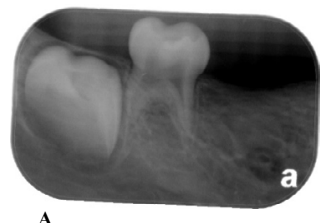

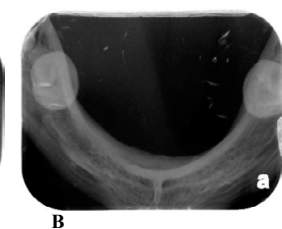

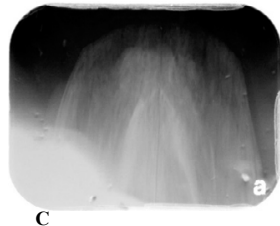

The patient did have a more developed orofacial musculature and was able to speak intelligible words compared to the first case, possibly due to the absence of a hearing impairment. The mother was also afflicted with ED but to a lesser extent, as well as the patient's sister and two cousins on his mother's side, all of who had different degrees of hypodontia. Genetic counseling was recommended to determine a more definitive inheritance pattern. The patient was very young for removable dentures, but since the cousins were successfully restored with removable partial dentures, the patient and mother were extremely motivated to have a maxillary complete overdenture and a mandibular complete denture fabricated. Prior to starting the impression procedures, enameloplasty of the primary maxillary incisors was completed to create a more dome-like contour. A maxillary complete overdenture and mandibular complete denture were fabricated as previously described and delivered. Due to his large protuberant lips, the buccal flange and borders of both dentures were thinned to a thickness of $1.5 \mathrm{~mm}$ to lessen the lip support. The patient did have a minor gag reflex during insertion initially, but the mother reported this subsided after a few days of wearing the prosthesis (Figure 7). The mother reported only minor problems and the patient adapted quickly, with improvements in speech, esthetics, and mastication, as well as his social behavior Recalls were established every three months to follow up on dentures as a rehabilitator of the oral motor function as well to evaluate the need for replacement of dentures due to growth

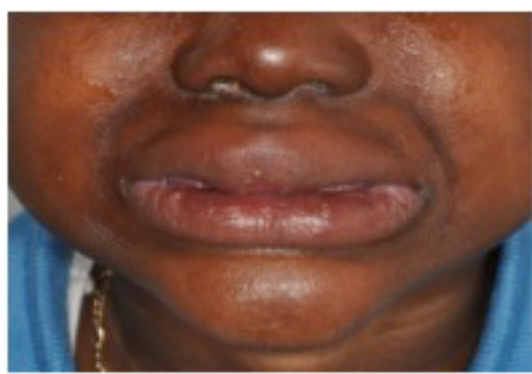

Figure 5. Facial view of patient with depressed nasal ridge, dry scaly skin, large protuberant lips, and evidence of a decreased occlusal vertical dimension.

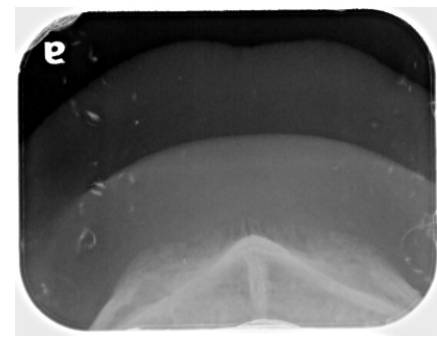

A

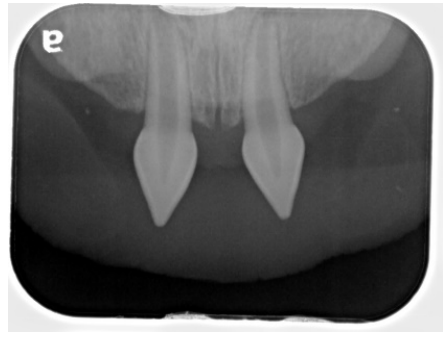

B
Figure 6. A. Mandible B. Maxilla Radiograph reveals only the primary maxillary centra incisors were present, note the sharp incisal edges and abnormal "spade-like" contours.

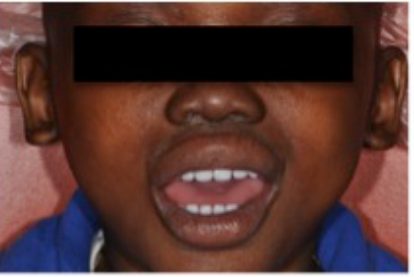

A

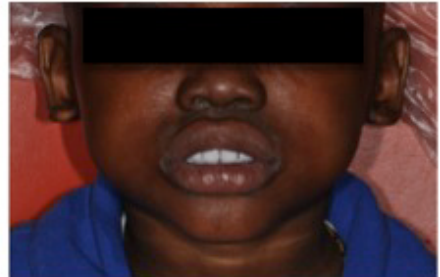

B palatal vault, and severe hypodontia (only primary maxillary central incisors present). Radiographic examination confirmed the clinical findings with only primary central incisors and no permanent teeth present (Figure 5).
Figure 7. A. Full facial view immediately after oral rehabilitation, illustrating restored vertical dimension of occlusion and harmonious facial height. B. Four months postinsertion of prosthesis, patient's self-esteem and confidence is much improved. 
and development of the arches.

\section{Summary}

Toddlers or young patients afflicted with ED have a marked challenge with the development of speech, poor esthetics, underdeveloped orofacial musculature, poor masticatory function and affected social and psychological development. Prosthetic oral rehabilitation seems highly recommended for these patients as early as 3 years of age to stimulate a normal oral functional development. However, the fit needs to be evaluated frequently and prostheses should be refabricated annually to account for growth. Oral rehabilitation of ED patients with removable prostheses at such a young age can prepare them for more definitive prosthetic treatment once growth is completed. The ability of the young patient to adapt to removable denture prostheses is rapid and the benefits of improved speech, esthetics, self-esteem, psychosocial development and overall function are evident.

\section{References}

1. Abadi BJ, Kimmel NA, Falace DA (1982) Modified overdentures for the management of oligodontia and developmental defects. ASDC J Dent Child 49: 123-126. [Crossref]

2. Arvedson, Clark H, Lazarus C, Schooling T, Frymark T (2010) The effects of oralmotor exercises on swallowing in children: an evidence-based systematic review. Dev Med Child Neurol 52: 1000-1013. [Crossref]

3. Bergendal B, Mcallister A, Steckse C (2009) Orofacial dysfunction in ectodermal dysplasias measured using the Nordic Orofacial Test-Screening protocol. Acta Odontol Scand 67: 377-381. [Crossref]

4. Bergendal T, Eckerdal O, Hallonsten AL, Koch G, Kurol J, et al. (1991) Osseointegrated implants in the oral habilitation of a boy with ectodermal dysplasia: a case report. Int Dent J 41: 149-156. [Crossref]

5. Bixler D, Saksena SS, Ward RE (1988) Characterization of the face in hypohidrotic ectodermal dysplasia by cephalometric and anthropometric analysis. Birth Defects Orig Artic Ser 24: 197-203. [Crossref]

6. Buyse ML (1990) Birth defects encyclopedia. St Louis: Blackwell Publishing; 597-98.

7. Champlin TL, Mallory SB (1989) Hypohidrotic ectodermal dysplasia: a review. J Ark Med Soc 86: 115-117. [Crossref]

8. Clarke A (1987) Hypohidrotic ectodermal dysplasia. J Med Genet 24: 659-663. [Crossref]

9. Clouston HR (1939) The major forms of hereditary ectodermal dysplasia: (With an Autopsy and Biopsies on the Anhydrotic Type). Can Med Assoc J 40: 1-7. [Crossref]

10. Cook WA, Kane FJ (1968) A family history of hereditary anhidrotic mesodermalectodermal dysplasia. J Am Dent Assoc 76: 1032-1037. [Crossref]

11. Cronin RJ Jr, Oesterle LJ, Ranly DM (1994) Mandibular implants and the growing patient. Int J Oral Maxillofac Implants 9: 55-62. [Crossref]

12. Ekstrand K, Thomsson M (1988) Ectodermal dysplasia with partial anodontia: prosthetic treatment with implant fixed prosthesis. ASDC J Dent Child 55: 282-284. [Crossref]

13. Freire-Maia N (1977) Ectodermal dysplasias revisited. Acta Genet Med Gemellol (Roma) 26: 121-131. [Crossref]

14. Freire-Maia N (1971) Ectodermal dysplasias. Hum Hered 21: 309-312. [Crossref]

15. Freire-Maia N, Lisboa-Costa T, Pagnan NA (2001) Ectodermal dysplasias: how many? Am J Med Genet 104: 84. [Crossref]

16. Guckes AD, Scurria MS, King TS, McCarthy GR, Brahim JS (2002) Prospective clinical trial of dental implants in persons with ectodermal dysplasia. J Prosthet Dent 88: 21-25. [Crossref]

17. Hinrichsen CFL (1963) Ectodermal dysplasia: case report. Aus Dent J 8: 101-5.

18. Jones JE, Yancey JM, Shawder KD (1978) Psychological concomitants of treating the dentally handicapped adolescent: report of case. ASDC J Dent Child 45: 313-318. [Crossref]

19. Kent G (1992) Effects of osseointegrated implants on psychological and social wellbeing: a literature review. J Prosthet Dent 68: 515-518. [Crossref]
20. Kraut RA (1996) Dental implants for children: creating smiles for children without teeth. Pract Periodontics Aesthet Dent 8: 909-913. [Crossref]

21. Levin LS (1988) Dental and oral abnormalities in selected ectodermal dysplasia syndromes. Birth Defects Orig Artic Ser 24: 205-227. [Crossref]

22. Davarpanah M, Moon JW, Yang LR, Celletti R, Martínez H (1997) Dental implants in the oral rehabilitation of a teenager with hypohidrotic ectodermal dysplasia: report of a case. Int J Oral Maxillofac Implants 12: 252-258. [Crossref]

23. Nordgarden H, Johannessen S, Storhaug K, Jensen JL (1998) Salivary gland involvement in hypohidrotic ectodermal dysplasia. Oral Dis 4: 152-154. [Crossref]

24. Nordgarden H, Storhaug K, Lyngstadaas SP, Jensen JL (2003) Salivary gland function in persons with ectodermal dysplasias. Eur J Oral Sci 111: 371-376. [Crossref]

25. Nortjé CJ, Farman AG, Thomas CJ, Watermeyer GJ (1978) X-linked hypohidrotic ectodermal dysplasia--an unusual prosthetic problem. J Prosthet Dent 40: 137-142. [Crossref]

26. Nowak AJ (1988) Dental treatment for patients with ectodermal dysplasias. Birth Defects Orig Artic Ser 24: 243-252. [Crossref]

27. Nussbaum B, Carrel R (1976) The behavior modification of a dentally disabled child. ASDC J Dent Child 43: 255-261. [Crossref]

28. O'Dwyer MR, Renner RP, Fergusen FS (1984) Overdenture treatment--one aspect of the team approach for the EEC syndrome patient. J Pedod 8: 192-205. [Crossref]

29. Oliver DR, Fye WN, Hahn JA, Steiner JF (1975) Prosthetic management in anhydrotic ectodermal dysplasia: report of case. ASDC J Dent Child 42: 375-378. [Crossref]

30. Ottenbacher K, Scoggins A, Wayland J (1981) The effectiveness of a program of oral sensory-motor therapy with the severely and profoundly developmentally disabled. Occup Ther J Res 1: 147-60.

31. Pigno MA, Blackman RB, Cronin RJ Jr, Cavazos E (1996) Prosthodontic management of ectodermal dysplasia: a review of the literature. J Prosthet Dent 76: 541-545. [Crossref]

32. Priolo M, Laganà C (2001) Ectodermal dysplasias: a new clinical-genetic classification. J Med Genet 38: 579-585. [Crossref]

33. Rathee M, Malik P, Dua M, Yadav V (2016) Early functional, esthetic, and psychological rehabilitation of preschool child with nonsyndromic oligodontia and anodontia in mixed dentition stage through conservative systematic approach: A case report with 5-year follow-up. Contemp Clin Dent 7: 232-235. [Crossref]

34. Renner RP, Kleinerman V (1980) Overdenture techniques in the management of oligodontia--a case report. Quintessence Int Dent Dig 11: 57-65. [Crossref]

35. Saksena SS, Bixler D (1990) Facial morphometrics in the identification of gene carriers of X-linked hypohidrotic ectodermal dysplasia. Am J Med Genet 35: 105-114. [Crossref]

36. Mittal M, Srivastava D, Kumar A, Sharma P (2015) Dental management of hypohidrotic ectodermal dysplasia: A report of two cases. Contemp Clin Dent 6: 414-417. [Crossref]

37. Smith RA, Vargervik K, Kearns G, Bosch C, Koumjian J (1993) Placement of an endosseous implant in a growing child with ectodermal dysplasia. Oral Surg Oral Med Oral Pathol 75: 669-673. [Crossref]

38. Snawder KD (1976) Considerations in dental treatment of children with ectodermal dysplasia. J Am Dent Assoc 93: 1177-1179. [Crossref]

39. Tape MW, Tye E (1995) Ectodermal dysplasia: literature review and a case report Compend Contin Educ Dent 16: 524-528. [Crossref]

40. Tanner BA (1988) Psychological aspects of hypohidrotic ectodermal dysplasia. Birth Defects Orig Artic Ser 24: 263-275. [Crossref]

41. Tarjan I, Gabris K, Rozsa N (2005) Early prosthetic treatment of patients with ectodermal dysplasia: a clinical report. J Prosthet Dent 93: 419-424. [Crossref]

42. von Wowern N, Harder F, Hjørting-Hansen E, Gotfredsen K (1990) ITI implants with overdentures: a prevention of bone loss in edentulous mandibles? Int J Oral Maxillofac Implants 5: 135-139. [Crossref]

43. Wisniewski SA, Kobielak A, Trzeciak WH, Kobielak K (2002) Recent advances in understanding of the molecular basis of anhidrotic ectodermal dysplasia: discovery of a ligand, ectodysplasin A and its two receptors. J Appl Genet 43: 97-107. [Crossref] 
Perry JE (2016) Smiling factory: Early rehabilitation of two young children with ectodermal dysplasia - Case reports

44. Wraith ED (1983) True ectodermal dysplasia. Dent Update 10: 662, 664-666, 668. [Crossref]
45. Wang Y, He J, Decker AM, Hu JC, Zou D (2016) Clinical outcomes of implant therapy in ectodermal dysplasia patients: a systematic review. Int J Oral Maxillofac Surg 45: 1035-1043. [Crossref]

Copyright: (C2016 Perry JE. This is an open-access article distributed under the terms of the Creative Commons Attribution License, which permits unrestricted use, distribution, and reproduction in any medium, provided the original author and source are credited. 